\title{
The Place of Cow Milk Allergy in Gastroenterology Practice
}

\section{Inek Sütü Alerjisinin Gastroenteroloji Pratiğindeki Yeri}

\author{
Caner Turan1, Maşallah Baran2, Miray Karakoyun1, Hüseyin Ozan Torun1, Sema Aydoğdu1 \\ 1 Ege University Faculty of Medicine, Department of Pediatric Gastroenterology, Izmir, Turkey \\ 2Tepecik Education and Research Hospital, Clinic of Pediatric Gastroenterology, Izmir, Turkey
}

\begin{abstract}
Aim: Cow milk allergy (CMA) prevalence is between 2-7.5\%; this prevalence decreases towards adolescence. In this study, children with cow milk allergy were evaluated retrospectively in terms of clinical findings at referral and responses to the treatment.

Materials and Methods: In this study, 36 children (Female/Male: 13/23) diagnosed with CMA were assessed in terms of diarrhea type, other accompanying system findings, laboratory values, serological tests, endoscopic findings, histopathological findings and treatment.

Results: Cow milk specific lgE (Fx2) was positive only in 11 cases (30\%). The most common symptom was discomfort $63.9 \%(n=23)$; frequency of gastrointestinal system findings were as follows: vomiting $52.8 \%(n=19)$, diarrhea $50 \%(n=18)$, bloody diarrhea $22.2 \%(n=8)$. Also, atopic skin findings $44 \%(n=16)$, chronic cough $38.8 \%(n=14)$ and reactive airway disease were observed in $22.2 \%(n=8)$ cases. Eosinophilic inflammation colitis was detected in patients undergoing colonoscopy. Of the 5 cases undergoing gastroduodenoscopy, results were compatible with eosinophilic esophagitis in 3 and with eosinophilic gastroenteritis in 2 . We determined that 33 of the cases (92\%) gave full response to elimination diet while in 2 cases symptoms persisted although their intensity decreased.

Conclusion: In children with CMA, most frequent complaints were discomfort, vomiting and diarrhea. In $47 \%$ of cases, more than one organ was involved. Eosinophilic infiltration was detected in all patients undergoing endoscopy. The Journal of Pediatric Research 2015;2(2):70-3
\end{abstract}

Key words: Cow milk allergy, eosonophilic gastroenteritis, elimination diet

Conflicts of Interest: The authors reported no conflict of interest related to this article.
ÖZET

Amaç: Çocukluk çağında inek sütü alerjisi (ISA) prevelansı \%2-7,5 arasındadır, erişkin yaşlara doğru bu sıklık azalmaktadır. Bu çalışmada, inek sütü alerjisi tanısı almış çocuklar başvuru anındaki klinik bulguları, laboratuvar özellikleri, tedaviye yanıtları yönünden retrospektif olarak değerlendirilmiştir. Gereç ve Yöntem: ISA tanısı alan 36 çocuk (Kadın/Erkek: 13/23), ishal tipi, eşlik eden diğer sistem bulguları, laboratuvar değerleri, serolojik belirteçler, endoskopik bulgular, histopatolojik bulgular ve tedavi yönünden değerlendirilmeye alınmıştır.

Bulgular: Inek sütü spesifik lgE (Fx2), sadece 11 hastada (\%30) pozitif olduğu görüldü. En sık bulgu olarak huzursuzluk \%63,9 (n=23) saptanıken gastrointestinal sistem bulgularından kusma \%52,8 ( $n=19$ ), ishal $\% 50$ ( $n=18)$, kanlı ishal \%22,2 ( $n=8$ ) oranında görüldü. Ayrıca, atopik deri bulguları \%44 (n=16), kronik öksürük \%38,8 (n=14), reaktif hava yolu hastalığı \%22,2 ( $n=8)$ olguda mevcuttu. Kolonoskopi yapılan hastalarda eozinofilik yangı içeren kolit bulguları saptandı. Gastroduodenoskopi yapılan 5 olgudan 3 'ünde eozinofilik özofajit, 2 olguda eozinofilik gastroenterit ile uyumlu bulgular saptandı. Olguların; 33'ü (\%92) eliminasyon diyetine tam yanıt verirken, 2 olguda semptomların azaldığı ancak devam ettiği görüldü.

Sonuç: ISA olan çocuklarda en sık huzursuzluk, kusma ve ishal şikayetleri görülmektedir. Olguların \%47'si birden fazla organ tutulumu göstermektedir. Endoskopi yapılan hastaların tamamınında eozinofilik infiltrasyon saptandı. The Journal of Pediatric Research 2015;2(2):70-3

Anahtar kelimeler: Inek sütü alerjisi, eozinofilik gastroenterit, eliminasyon diyeti

Çıkar Çatışması: Yazarlar bu makale ile ilgili olarak herhangi bir çıkar çatışması bildirmemiştir. 


\section{Introduction}

Cow milk allergy (CMA) prevalence is reported to be between 2 and $7.5 \%$ in childhood (1). This prevalence decreases to $0.1-0.5 \%$ towards adolescence (2). This difference can be attributed to diagnostic methods and elimination diet treatments (3). CMA is seen only in babies taking mother milk. Early diagnosis and proper treatment is important in the growth and development of patients. There are two different mechanisms of the pathology of the disease: one is with IgE antibodies against cow-milk proteins and the other in which IgE doesn't play a role but IgG role playing immune reactions are observed (2). In lgE mediated cases; findings such as urticaria, angioedema, vomiting, atopic dermatitis, acute exacerbations are observed in two hours after encountering cow milk protein. In non-lgE mediated cases, findings emerge typically late (after 20 hours) (4), as the most frequent ones are atopic dermatitis and gastrointestinal system findings. Skin tests and specific IgE tests are found positive in a higher proportion in early reaction giving cases compared to late reaction giving cases. Because of this reason, laboratory methods using milk cow are not definitive in diagnosis. Due to this uncertainty, diagnosis logarithms based on elimination diets are developed (3). IgE level and age of patient plays an important role in CMA positive cases. In this study, the aim is to evaluate referral clinical findings, laboratory properties and responses to treatment of cases with the diagnosis of CMA.

\section{Materials and Methods}

Thirty-six patients diagnosed with cow milk allergy between 2009 and 2011 in Tepecik Research and Education Hospital, Pediatric Gastroenterology Policlinic (20/1200) and in a private pediatric gastroenterology center (16/400) were included in this study. Laboratory values at, the time of diagnosis, referral clinical findings, endoscopic investigations, responses to elimination diets and atopic disease progression were recorded retrospectively. In terms of clinical findings, patients with findings seen in Table I, were put on two-week elimination diets free of cow milk and cow milk products and their clinical responses were assessed. For patients responding well to treatment and whose findings recurred after encountering cow milk protein again, CMA diagnosis was made and they were given a long-term (12-24 month) elimination diet. In cases where the infants were taking mother milk as elimination diet, the diet was given to the mother and she was not given cow milk or foods containing its products in any way. For formula feeding cases, full hydrolised or amino-acid based formulas were used; for cases receiving additional nutrient supply, products not containing cow milk were used. Files of all cases were scrutinized for IgE, specific lgE, hemoglobin, hematocrit, trombocyte count, leukocyte count, eosonophil count and endoscopic findings data.

\section{Statistics}

Case data was assessed with SPSS 16 database program descriptive statistical analyzer, $p$ value of $p<0.05$ was accepted as significant.

\section{Results}

In this study, 23 of the patients were male (64\%), mean age at diagnosis was $12 \pm 12$ months (min: 2 days-maximum: 54 months) and 15 cases were detected to be under 6 months (42\%), 9 cases (25\%) were younger than 1 year old.

When clinical findings were evaluated, there was discomfort in 23 cases (63.9\%); vomiting in 19 (52.8\%); diarrhea in 18 cases (50\%); bloody diarrhea in 8 (22.2\%) constipation in 5 cases (13.9\%). Skin findings were present in 17 cases: 16 of them had dermatitis (44\%) and 1 angioedema. Respiratory findings were chronic cough in 14 cases (38.8\%), reactive airway disease in 8 (22.2\%) (Table I). Atopy history was present in 13 cases (36\%).

When organ involvement was taken into consideration according to systems, the following values were found: only gastrointestinal system findings in 12 cases (33\%), only skin findings in $4(11 \%)$, only respiratory findings in 3 of them (8\%) (Table II). In other 17 cases (47\%), more than one organ involvements were detected (Table III).

Hemogram values were as follows; mean hemoglobin value was $11.3 \pm 1.4 \mathrm{gr} / \mathrm{dl}$ (8.2-14); thrombocyte count 425000 $\pm 193000 / \mathrm{mm}^{3}$ (183000-1050000); leucocyte count $11600 \pm 5500 / \mathrm{mm}^{3}$ (5100-29000); eosonophile percentage value mean was $5.3 \pm 5.1(0.2-23)$.

Mean total IgE value of patients was detected as $102 \pm 164 \mathrm{mg} / \mathrm{dl}$ (3-679). Cow milk specific protein IgE was negative in 25 cases (69.4\%), it was Class 1 in 3 cases (8\%), Class 2 in $4(11 \%)$, and Class 3 in 4 cases $(11 \%)$.

When cow milk specific lgE was assessed on organ involvement, it was detected as positive in 6 of 17 patients with more than one organ involvement (35\%), in 1 of 12 patients with only gastrointestinal system involvement (8\%), in 1 of 3 patients with only respiratory findings (33\%), in 3 of 4 patients with only skin changes (75\%). In all cases, in 4 of $8(50 \%)$ patients with reactive airway disease and in 7 of $16(43 \%)$ patients with atopic skin findings, specific IgE was detected as positive.

Endoscopic investigation was carried out on 10 of 36 patients. Upper gastrointestinal system endoscopy done for on 5 patients, colonoscopic investigation on another 5 patients. When 5 cases undergoing gastroduedonoscopy were assessed, eosonophilic infiltration in bulbus and

\begin{tabular}{|l|l|l|l|l|l|}
\hline \multicolumn{7}{|l|}{ Table I. Cow milk allergy clinical findings } \\
\hline Gastrointestinal System & $\mathbf{n}$ & $\%$ & $\begin{array}{l}\text { Respiratory } \\
\text { System }\end{array}$ & $\mathbf{n}$ & $\%$ \\
\hline Vomiting & 19 & 52.8 & Chronic Cough & 14 & 22.8 \\
Small intestine type diarrhea & 18 & 50 & $\begin{array}{l}\text { Reactive } \\
\text { airway disease }\end{array}$ & 8 & 22.2 \\
Large intestine type diarrhea & 8 & 22.2 & & & \\
Constipation & 5 & 13.9 & & & \\
\hline Skin findings & & & Other & & \\
\hline Atopic findings & 16 & 44 & Discomfort & 23 & 63.9 \\
Angioedema & 1 & 2.7 & & & \\
\hline
\end{tabular}




\begin{tabular}{|l|l|}
\hline Table II. Symptom Distribution according to organ involvement \\
\hline Organ Involvement & \\
\hline Gastrointestinal system & $\begin{array}{l}\text { Vomiting } \\
\text { Diarrhea } \\
\text { Bloody diarrhea } \\
\text { Constipation } \\
\text { Iron deficiency anemia }\end{array}$ \\
\hline Skin & $\begin{array}{l}\text { Atopic dermatitis } \\
\text { Urticaria (drug, infection, or other known } \\
\text { reasons excluded) } \\
\text { Swelling in eyes and lips, angioedema }\end{array}$ \\
\hline Respiratory system & $\begin{array}{l}\text { Chronic cough } \\
\text { Wheezing }\end{array}$ \\
\hline General symptoms & $\begin{array}{l}\text { Resistant discomfort ve colic pain (irritability } \\
\text { longer than 3 hours, 3 days a week, longer } \\
\text { than 3 weeks) }\end{array}$ \\
\hline
\end{tabular}

Table III. Patient distribution according to patients and specific lgE

\begin{tabular}{|l|l|l|l|}
\hline & $\mathbf{n}$ & $\%$ & Specific IgE Positive (\%) \\
\hline Only gastrointestinal system & 12 & 33 & $1(8 \%)$ \\
\hline Only respiratory system & 3 & 8 & $1(33 \%)$ \\
\hline Only skin findings & 4 & 11 & $3(75 \%)$ \\
\hline More than one organ involvement & 17 & 47 & $6(35 \%)$ \\
\hline
\end{tabular}

duedoneum was detected in 2 of them; serious esophagitis findings were detected in 1 case and eosonophilic esophagitis findings were detected in 2 of the cases. In the colonoscopy of 5 patients with bloody diarrhea, eosonophilic inflammation colitis findings were detected. In macroscopic appearance of mucosa; in 1 case, hemorrhagic ulceration was observed while in other 4 cases appearance of 'chicken skin' nodularity (lympho-nodular hyperplasia) findings were observed. In all cases undergoing colonoscopy, specific lgE levels were detected as negative. In two cases, specific IgE levels were Class 2 and Class 3 positive. There were also respiratory findings in these two cases.

Elimination diets were given to all cases under the age of 2. Amino-acid based formula was used. Elimination diet of taking only mother milk was given to 7 cases and amino-acid based formula was added to the diet in the 4-6 month- olds. Findings were detected in all of them.

When responses of cases to elimination diets were observed, it was seen that 33 cases (92\%) gave full response to treatment, there was partial response in 3 cases (colitis inflammation findings not fully resolved in 2 cases, continuation of vomiting in 1 case altough its intensity greatly decreased). In two cases with partial colitis findings, low dose steroid therapy was added for 4-8 weeks besides elimination diet. The average diet time was 15 months in cases; in 25 cases (69\%) the diet was terminated. One week after the termination of the diet, findings recurred mildly in 1 case (cough finding) and the diet was started again.

\section{Discussion}

Infants taking mother milk encounter cow milk proteins as the first other nutrient. This encounter can be directly with cow milk or it can be by cow milk based formulas. Reactions due to cow milk exposure can range from mild reactions to chronic,long-term or life-threatening reactions (4). When demographic properties of CMA were evaluated, male/female proportion was found as $65 \% / 35 \%$ in one study (5) and as 30.3\%/69.7\% in another study (6). Cow milk allergy frequency was reported as $1.9-7.5 \%$ in epidemiologic studies. Studies completed in Turkey are very restricted. In our study, it was detected as $2.25 \%$. In the study performed, cow milk allergy was observed mainly in infancy (7). In our study $75 \%$ of cases were infants as well.

Generally there are $\lg \mathrm{E}$ mediated allergic mechanisms at the basis of cow milk allergy (8). Reactions against cow milk often develop in the first 2 hours. These reactions are seen as skin, respiratory system, gastrointestinal system and cardiovascular system findings. Eosonophilic gastroenteritis and atopic dermatitis findings occur by $\lg E$ and non-lgE mediated reactions (9). In CMA, upper gastrointestinal system findings occur in the first minutes, while lower gastrointestinal system findings appear later. Findings such as vomiting, discomfort, eosonophilic esophagitis, eosonophilic gastroenteritis, allergic proctocolitis and enterocolitis can also seen. Vomiting is the most frequent GIS finding (9). In a study carried out in Norway, in CMA diagnosed infants, pain was present in $48 \%$, gastrointestinal symptoms in $32 \%$, respiratory findings in 27\%, atopic dermatitis in $4.5 \%$ (10). In a study, the most frequent symptom was skin findings (85\%), followed by GIS findings such as vomiting, bloody diarrhea, gastroesophagial reflux (46\%), lower respiratory findings such as wheezing, cough, stridor (14\%) and upper respiratory system findings such as rhinitis, nasal congestion (6\%) (5).

In another study, the most frequent symptoms were detected in the order of skin findings (74\%), gastrointestinal findings (46\%), respiratory system findings (40\%) (11). Gastrointestinal system findings were detected in $60 \%$, skin changes in 50-60\%, respiratory system findings in 20-30\%, anaphylaxis in 9\% in patients diagnosed with CMA (4-12).

In our study, consistent with the literature, the most frequent symptoms were gastrointestinal ones (81\%) -vomiting (the most frequent symptom), diarrhea, constipation, iron deficiency anemia-; the less frequent symptoms were skin findings (59\%) -atopic dermatitis, urticaria, angioedemaand the least frequent symptoms were respiratory system findings $(56 \%)$ - chronic cough, wheezing.

The family history of atopy is one of the most important risk factors for persistant CMA besides allergic rhinitis, asthma, eczema, skin or gastrointestinal system findings (13). In Spain, in a study done on 1657 infants, CMA prevalence was detected as $0.36 \%$, while prevalence among infants with atopic family history was detected as 3.8\% (14). In another study, 115 infants diagnosed with CMA were followed for 24-114 months and familial atopy was detected in $49.6 \%$ of these patients (15). In another study, it 
was reported that there was $47.6 \%$ familial atopy in infants diagnosed with CMA (16). In our study, familial atopy was detected in 13 cases (36\%).

Double blind placebo control food comparisons test (DBPCFC) is seen as the gold standard test in allergy diagnosis. But its use is restricted as it is a time-consuming expensive and difficult test. For this reason generally clinical history, physical examination, response to diet and recurrence of findings when repeating the diet, skin tests and specific $\lg$ E tests are used for diagnosis (17). In our study, diagnosis was made based on elimination diet and recurrence of clinical findings when patients were given again the eliminated cow milk diet. And findings for diagnosis were reinforced by laboratory tests and endoscopic methods. In 92\% of the cases that were given the elimination diet, full recovery was observed; in 2 cases low dose steroid therapy was added for 4-8 weeks because of the severity of clinical findings. When the diet was terminated, in 25 cases there was no recurrence; and in 1 case cough complaint was observed.

Non-lgE mediated mechanisms are responsible for cases with colitis.In the study with skin prick test specific IgE was detected as negative while with patch test done with mother milk it was detected as positive in all cases (18). Findings were observed to regress with the diet given to the mother. Findings of this study are consistent with endoscopic findings we found in our cases; with general appearance of colon as nodular. In more severe cases, ulcerations were found on mucosa as we detected in 2 of our cases.

Measured total IgE level was not found to be significantly related to cow milk allergy. But in some cases, high levels were detected. When specific lgE levels are considered, its $75 \%$ positivity in patients with skin changes can be important. In our study, atopic skin changes of $44 \% \quad(n=16)$ and specific lgE level positivity of $30.6 \% \quad(n=11)$ show parallelism. Also 92\% negativity level of specific lgE serology in patients with only GIS findings supports the fact that non$\lg \mathrm{E}$ mechanisms are dominant in these cases.

In a significant proportion of cases, findings regressed substantially with the elimination diet given to the mother and/or amino-acid based formulas (92\%). No difference was observed in response to the diet among different organ involvements.

In specific IgE positive cases, the risk of atopic diseases such as asthma, atopic dermatitis and rhinoconjonctivitis development is greater than specific IgE negative cases (19). Reactive airway disease history was detected in $22 \%(n=8)$. In half of these cases, specific IgE was found as positive. Although we don't have enough data to evaluate how many of these cases are candidates for asthma, we propose followup of these cases for this.

As a result, the most frequent symptoms in children with CMA were discomfort, vomiting and diarrhea. In 47\%, more than one organ was involved. In serologic study of the patients, specific lgE was detected as negative in $69 \%$ of cases. Eosonophilia was detected in all cases undergoing endoscopy. Full recovery in clinical findings was observed in patients who were put on elimination diet.

\section{References}

1. Jarvinen KM, Suomalainen H. Development of cow's milk allergy in breast-fed infants. Clin Exp Allergy 2001; 31:97887.

2. Crittenden RG, Bennett LE. Cow's milk allergy: a complex disorder. J Am Coll Nutr 2005; 24:82-91.

3. Vandenplas $Y$, Koletzko S, Isolauri E, et al. Guidelines for the diagnosis and management of cow's milk protein allergy in infants. Arch Dis Child 2007; 92:902-8.

4. Hill DJ, Banister DG, Hosking CS, Kemp AS. Cow milk allergy within the spectrum of atopic disorders. Clin Exp Allergy 1994; 24:1137-43.

5. Skripark JM, Matsui EC, Mudd K, Wood RA. The natural history of IgE mediated cow's milk allergy. J Allergy Clin Immunol 2007; 120:1172-7.

6. Doğruer D, ve ark. Alerjik Hastalıkların Sıklığı ve Gelişiminde Etkili Risk Faktörleri, Doğum Kohort Çalışması. C.U.T.F. Pediatrik Alerji ve Immunoloji Bilim Dalı, Adana; 2012.

7. Steinke M, Fiocchi A, Kirchlechner V, et al. Perceived food allergy in children in 10 European nations. A randomised telephone survey. Int Arch Allergy Immunol 2007; 143:290-5.

8. Wal JM. Cow's milk proteins/allergens. Ann Allergy Asthma Immunol 2002; 89:3-10.

9. NIAID-Sponsored Expert Panel, Boyce JA, Assa'ad A. et al. Guidelines for the diagnosis and management of food allergy in the United States: report of the NIAID-sponsored expert panel. J Allergy Clin Immunol 2010; 126:1-58.

10. Kvenshagen B, Halvorsen $R$, Jacopsen $M$. Adverse reactions to milk in infants. Acta Pediatr 2008; 97:196-200.

11. Hidvegi E, Cserhati E, Kereki E, Savilahti E, Arato A. Serum immunoglobulin $\mathrm{E}$, IgA, and IgG antibodies to different cow's milk proteins in children with cow's milk allergy: association with prognosis and clinical manifestations. Pediatr Allergy Immunol 2002; 13:255-61.

12. Bishop JM. Hill DG, Hosking CS. Natural history of cow's milk allergy: clinical outcome. J Pediatr 1990; 116:862-7.

13. Fiocchi $A$, Schünemann $H J$, Brozek $J$, et al. Diagnosis and Rationale for Action Against Cow's Milk Allergy (DRACMA): a summary report. 2010; 126:1119-28.

14. Sanz Ortega J, Martorell Aragonés A, Michavila Gómez A, Nieto García A; Grupo de Trabajo para el Estudio de la Alergia Alimentaria. Incidence of IgE-mediated allergy to cow's milk proteins in the first year of life. An Esp Pediatr 2001; 54:536-9.

15. Suh J, Lee H, Lee JH, et al. Natural course cow's milk allergy in children atopic dermatitis. J Korean Med Sci 2011: 1152-8.

16. Altıntaş $D$, Güneşer $S$, Evliyaoğlu N, Yüksel B, Atici A, Serbest M. A prospective study of cow's milk allergy in Turkish infants. Acta Pediatr 1995; 84:1320-1.

17. Mendonça RB, Franco JM, Cocco RR, et al. Open oral food challenge in the confirmation of cow's milk allergy mediated by immunoglobulin E. Allergol Immunopathol (Madr) 2012; 40:25-30.

18. Lucarelli $S$, Frediani T, Zingoni AM, et al. Food allergy and infantile autism. Panminerva Med 1995; 37:137-41.

19. Malmberg LP, Saarinen KM, Pelkonen AS, Savilahti E, Mäkelä MJ. Cow's milk allergy as a predictor of bronchial hyperresponsiveness and airway inflammation at school age. Clin Exp Allergy 2010; 40:1491-7. 